\title{
GREEN CRITIQUE IN A RED ENVIRONMENT: EAST EUROPEAN ART AND ECOLOGY UNDER SOCIALISM
}

MAJA FOWKES, REUBEN FOWKES

In its report on the first UN Summit on the Human Environment, held in Stockholm from June 5-16, 1972, the Zagreb cultural weekly Telegram vividly depicts the debates that raged around "the most diverse aspects of human existence on the planet," and the ecological perils of a "world that man has created and is now threatening to destroy. ${ }^{1}$ "To the young delegate who wrote the account, it was clear that a solution to the ecological crisis could only be found in "collective action by all the inhabitants of the earth," while he also disclosed that major disagreements remained over the path to be taken, which are often "the fruit of different political and economic interests," rather than ecological ones. Also described in the article are the loud disputes over the I972 book The Limits to Growth, the pivotal study written by MIT scientists who used computer models to gauge the ill effects of human population growth on economics and the environment; such disputes highlight the developing world's criticism of the work's "elitist position" and its "reliance on the laws of capitalist economics of the West." Overall, the piece vibrantly conveys the atmosphere of urgency that infused both the official conference and the numerous parallel

I Nenad Prelog, “Dilema: Stagnacija ili propast. Konferencija ujedinjenih nacija o covjekovoj okolini" [Dilemma: Stagnation or Disaster. UN Conference on the Human Environment], Telegram, June 23, I972, 9. Authors' translation. 
gatherings attended by environmental scientists, nature conservationists, and members of the counterculture. ${ }^{2}$

The informed discussion of global ecological issues in the Croatian public sphere around the time of the Stockholm Summit surfaced in the politically polarized atmosphere of Tito's crackdown on the Croatian Spring autonomy movement. In the wake of the crushing of nationalist aspirations, the public prominence of environmentalism provided a potential substitute and ideological decoy within the fractured terrain of Yugoslav politics. Elsewhere in the socialist world, information about the growing international debate on the need for collective action to confront the looming ecological crisis was deliberately kept out of the public eye by the authorities, in accordance with their decision to boycott the summit itself. As a result, the spread of ecological thinking behind the Iron Curtain was not due to official proclamations and publications, but rather emerged from below through the ideas and actions of individuals within grassroots movements, including countercultural formations in which artists also played a significant role.

The ostensible reason for the Soviet decision to absent the Socialist Bloc from the pivotal global discussions in Stockholm was disagreement over the representation of East Germany at the United Nations. ${ }^{3}$ However, the roots of the failure of the Eastern Bloc to engage with the new debate on the state of the environment went deeper and can be located in the persistence of a hostile attitude to nature that was formed during Stalinism and remained virtually unchanged in the wake of the de-Stalinization that began in the mid-I950s. The consequences of the Soviet rejection of the first tentative steps to establish an international framework to tackle environmental crisis would also turn out to have a much greater impact than first appeared in 1972 . The hollowness of the official story that "ecological problems will be solved" automatically once all "nations become socialist" ${ }^{4}$ was exposed in the following decade, with the leaking of a secret report on the effects of pollution in

\footnotetext{
Ibid.

The question of the international recognition of East Germany was resolved in December I972, half a year too late for the Stockholm Summit, with the German Democratic Republic becoming a full member of the UN the following year. See also Ken Conca and Geoffrey D. Dabelko, eds., Green Planet Blues: Environmental Politics from Stockholm to Johannesburg (Boulder, CO: West View Press, 2004), 4.

4 The official Soviet response to environmentalism was characterized by one commentator in the period; see Howard L. Parsons, ed., Marx and Engels on Ecology (Westport, CT: Greenwood Press, I977), I03.
} 
Czechoslovakia ${ }^{5}$ and unprecedented mass demonstrations in front of the Parliament in Budapest against plans to build a dam on the Danube between Slovakia and Hungary, a plan protesters seized on as "a symbol of the state socialist system's disregard for the aesthetic and historical importance of the landscape." ${ }^{\prime 6}$ In the wake of the Chernobyl disaster in I986, environmental campaigns escalated further across Eastern Europe, becoming a key factor in the rise of civil movements that culminated in the system-changing revolutions of 1989 .

The reckless exploitation of natural resources with little consideration for its effects on the environment was endemic to the whole Eastern Bloc, marked by the building of massive industrial complexes, which gave rise to severe water and air pollution that damaged forests, contaminated agricultural land, and caused health problems from asthma to lead poisoning. ${ }^{7}$ While the model of environmentally insensitive industrial development was commonplace across the region, where differences among the states did emerge was in terms of the availability of information about the degree of pollution and its public health risks, as well as the ease of access to the ecological debates of the time. Modulations in the patterns of information exchange regarding the ecological crisis both within particular states and across the porous border of the Iron Curtain were among the principal factors influencing the direction of artistic engagements with the environment.

Although environmental awareness in Eastern Europe during the I960s and I970s generally lacked a public or civic dimension, it was still present as an underlying current within neo-avant-garde and dissident circles, which in effect incubated ecological thinking during the long chill of the Brezhnev years. A profound concern with ecology, understood through the environmental perspective of the period in terms of the impact of human actions on both urban and natural surroundings, was manifested across a range of approaches and to national Moments of Change: Europe 1945, 1968, 1989, ed. Gert-Rainer Horn and Pedraic Kenney (Lanham, MD: Rowman and Littlefield, 2004), I74.

6 Krista Harper, Wild Capitalism: Environmental Activists and Post-Socialist Political Ecology in Hungary (Boulder, CO: East European Monographs, 2006), 33.

7 For example, the industrial complex around Nowa Huta (New Mill) and the region of Upper Silesia was responsible for $50 \%$ of Polish air pollution by the I980s; see Jacek Wódz and Kazimiera Wódz, "Environmental Sociology in Poland," in Environment and Society in Eastern Europe, ed. Andrew Tickle and Ian Welsh (Boston: Addison Wesley Longman, I998), I06. See also the regional comparisons in Joseph Alcamo, ed., Coping with Crisis in Eastern Europe's Environment (New York: CRC Press, I992). 
varying levels of explicitness in the practice of the generation of conceptual artists that emerged in the wake of the social, political, and cultural transformations of I968.

The challenge posed by the ecological question for socialist regimes, as it emerged with new urgency as an intellectual and social current from the late ig6os onward, went to the core of the social and economic model built up in the Soviet Union since the Russian Revolution and exported to the Eastern Bloc after 1945. While in the I920 conservationism flourished, based on the protection of "selfcontained natural communities" that embodied "unbroken webs of life," the accelerated industrialization of the Stalinist era, which recognized no limits to the state's requisition of natural resources, completely drowned out the calls of early Soviet environmentalists for restraint in interfering with natural systems. The process of deStalinization in the Khrushchev era crucially failed to soften the official party line on the environment, with continuity in the domineering and exploitative approach to nature symbolized by vast schemes to reroute rivers from north to south, megalomaniac interventions in the natural environment that were mimicked on a smaller scale across the satellite states of Eastern Europe. ${ }^{?}$

The wide-ranging engagements of East European neo-avant-garde art with ecology can be seen on one level as a response to the despoliation of the environment caused by breakneck industrial development. They also arose in reaction to the ideologically hostile state-communist attitude to nature, which not only saw it in purely practical terms as a resource for exploitation, but went one step further by treating nature, which provocatively existed outside the absolute control of the party, almost as an enemy of the state, "a consciously anti-socialist force that needed to be suppressed." ${ }^{10}$ In the wake of the neo-Marxism of the I960s, signs of a latent ecological orientation in Marx's early writings on alienation brought an additional layer of complexity to the environmental critique that surfaced in countercultural circles and informed neo-avant-garde art practice in Eastern Europe. ${ }^{11}$

8 Douglas R. Weiner, Models of Nature: Ecology, Conservation, and Cultural Revolution in Soviet Russia (Pittsburgh, PA: University of Pittsburgh Press, I988), 232.

9 See Douglas R. Weiner, A Little Corner of Freedom: Russian Nature Protection from Stalin to Gorbachev (Berkley: University of California Press, I999), 4I4-28.

Io Ibid., I68.

II See, for example, Rudi Supek, Ova jedina zemlja [This Only Earth] (Zagreb: Globus, I973). 
Artists that engaged with environmental questions in the period had to deal with all of the complexities and ideological intricacies of ecology in the context of Eastern Europe, as well as operate within the restrictions and pressures of the political system of real existing socialism, with fluctuating periods of liberalizing cultural thaws followed by the return of deep ideological freeze. The suppression of the Prague Spring in I968 was the most dramatic ideological backlash of the era, and it also colored the artistic responses to the natural environment in socialist Eastern Europe, since in its wake the political and cultural landscape was completely transformed, and a generation lost all illusions about the possibility of "socialism with a human face." ${ }^{2}$ As a result, many neo-avant-garde artists gave up on hopes for a reformed socialist system and increasingly directed their artistic energies in new directions, ecological ones included.

The reconstruction of the wide-ranging environmental engagements of conceptual artists in the period involves excavating their activities from the obscurity that resulted from the invisibility of ephemeral neo-avant-garde artistic actions realized outside institutional structures and from the deep-rooted suspicion toward environmental orientations within a critical context in which modernist aesthetic categories retained their dominance as a bulwark against the official doctrine of Socialist Realism. At the same time, post-communist reassessments of the legacy of the East European art of the I960s and I970s have tended to ignore the ecological aspect of the neo-avant-garde, sidelining what has been regarded as the "soft politics" of environmental concern in order to privilege artistic practices that could be easily situated within a binary division of the art of the period into a compliant official and a rebellious unofficial art. The present account is based on extensive research that aims to illuminate this particular art historical blind spot to reveal the importance of ecology in the work of East European neoavant-garde artists. ${ }^{13}$

The question at the core of this inquiry is how East European artists informed by an environmental agenda expressed their critique of actual existing socialism, navigating official state ideologies and nationalist undercurrents, while still maintaining a strategic distance

I2 See Claire Bishop and Marta Dziewanska, eds., 1968-1989: Political Upheaval and Artistic Change (Warsaw: Museum of Modern Art, 20II).

I3 See Maja Fowkes, The Green Bloc: Neo-avant-garde Art and Ecology under Socialism (Budapest: Central European University Press, forthcoming in 20I5). 
from the values and models of the capitalist order on the other side of the Cold War divide. These intricate positions are examined through the environmentally and scientifically informed practice of Slovak artist Rudolf Sikora, the countercultural quest for unity with nature and the cosmos of Slovenian group OHO, the phenomenological immersion in the natural world of Czech artist Petr Štembera, and the ecologically oriented public art of Croatian group TOK. The nuanced political and artistic terrains of the extinguished socialist realities of the former federations of Czechoslovakia and Yugoslavia provide a backdrop for contextually informed comparison.

\section{RUDOLF SIKORA}

A little known work by Rudolf Sikora entitled Czechoslovakia 1969 provides a window into the seismic changes brought by the process of normalization that followed the brutal crushing of the Prague Spring. Divided into four levels, Sikora's collage starts with an aerial photograph of a crowd of people, followed by a transition zone, which turns into blue sky, and finally a luminous night sky. Against this background ascends a sequence of cutouts in the shape of Czechoslovakia, which remain invisible in the lowest section, immersed in the multitude of people, with clear associations with the mass movements of I968; as the outline rises up, it transforms into an earthy brown, followed by a deep red, the symbolism of which in 1969 is evident; finally, the country is filled with a map of the constellations and elevated into the universe. The attraction of the cosmic metaphor for Sikora was that it provided both a means to talk about the tragedy that had befallen the country and an escape from the increasingly restrictive social and political situation, since interplanetary realms were beyond the reach of the state apparatus. ${ }^{14}$ Through the dislocations of his country in the collage, it is possible to perceive the artist's exploration of a sense of belonging, elevating himself above national borders to take on a more cosmopolitan position within the fractured social terrain of post-I968 Eastern Europe.

Sikora's first artistic action in the countryside took place during

I4 Sikora was one of a number of Slovak neo-avant-garde artists who were attracted to cosmic imagery in the time of normalization; see Daniel Grún, "Der Kosmos der slowakischen Neoavantgarde zwischen Utopie, Fiktion und Politik," in Crossing 68/89: Grenzüberschreitungen und Schnittpunktezwischen den Umbrüchen, ed. Danyel von Jürgen (Berlin: Metropol, 2008), I36-55. 


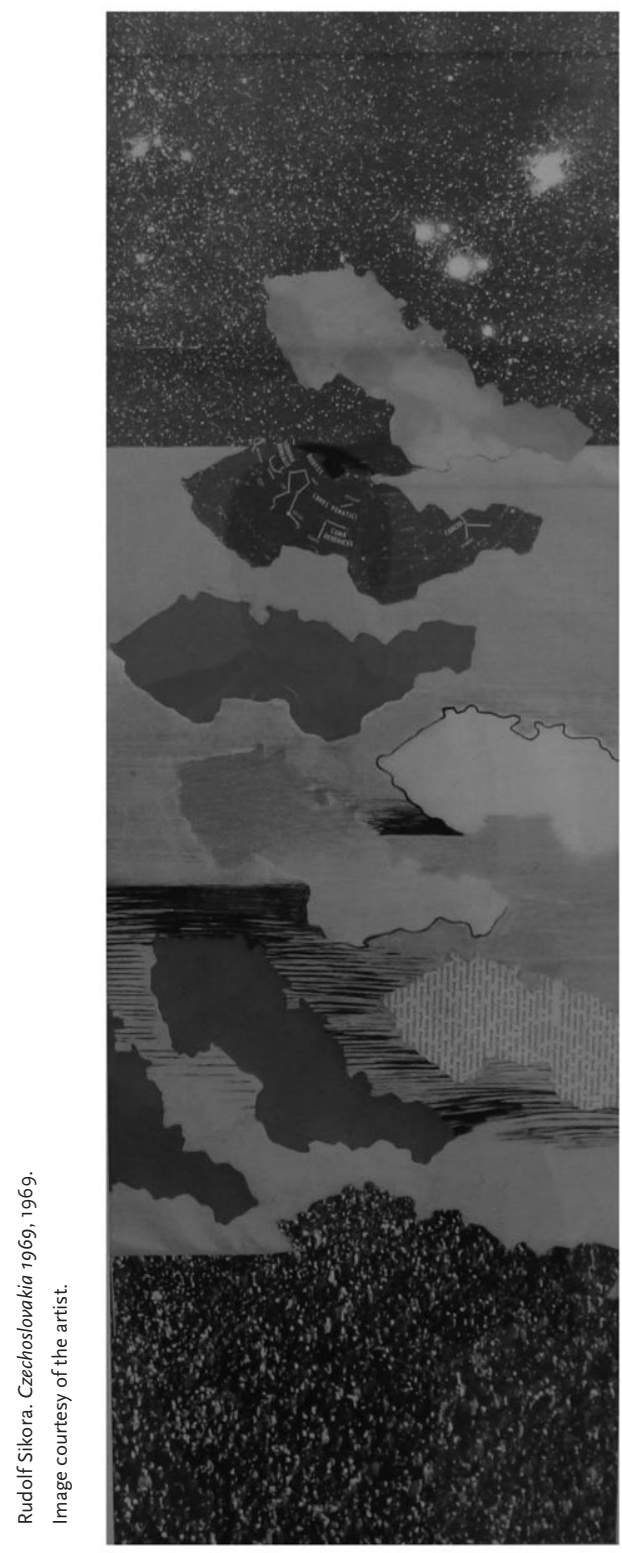

the winter holidays of I970 on the outskirts of Zvolen, an industrial town in central Slovakia, where the artist inscribed nine large arrows into the snow, pointing the way between socialist housing blocks toward the surrounding fields and woods. In Out of Town, which would become an iconic work of the Slovak neo-avant-garde, ${ }^{15}$ the artist shifted his focus from the problem of the representation of space to instead actively engage with it by intervening in the actual environment. Although Sikora later admitted that the work demonstrated his "still only felt fear of the polluted environment," expressed through the idea of leaving "dirty spaces for clean nature,"16 the arrows in the snow would turn out to have directed the artist toward the exploration of ecological problems and the human relationship to the environment in a more complex way.

In I97I Sikora realized a poster entitled Time ... Space I in which he dealt with temporal and spatial relations, posing the question of how to locate humanity within those parameters. In the poster, a group of images shows the universe, galaxies, the solar system, planet Earth, and humanity, with several white arrows intersecting them. In the text below, the artist provides scientific information about phenomena such as the size of the universe and age of the planet, while listing human virtues such as work, love, bravery, and devotion,

I5 See, for example, the catalog of the exhibition of Slovak land art: Daniela Čarna, Z mesta von/Out of the City: Land Art (Bratislava: City Gallery, 2007).

I6 Rudolf Sikora, "Epilogue 2006," in Rudolf Sikora: Against Myself (Prague: National Gallery, 2006), 275 . 
which are counterposed with the vices of war, poverty, and selfishness. In this way, Sikora brought an ethical dimension to dry scientific facts about the universe, as well as a timely understanding that human behaviors and attitudes toward the ecosystems that support life on earth are inextricably connected to issues of social justice, economic development, and personal well-being.

Sikora's thinking about ecology was profoundly influenced by The Limits to Growth: the artist referred to the book, commissioned by the Club of Rome, as "my other bible of the early '7os." ${ }^{17}$ It is remarkable that at a time when only a small circle of specialists had access to environmental literature in central scientific libraries, and even "within the environmental movement there were few people who had deep knowledge of the works of the Club of Rome," 18 the artist managed to obtain substantial information about the publication. Sikora was well-connected with dissident scientists and held weekly gatherings in his studio, where they discussed scientific, ecological, and artistic questions; in fact, it was through him that environmental discourse became part of the Slovak unofficial art scene and was later included in the art historical narrative of the period. ${ }^{19}$

The fruits of this interdisciplinary exchange could be seen in Sikora's triptych Cuts through Civilization from I972, which consists of a cross-section of the earth containing geological layers of the planet's crust and atmospheric layers above. The central part, which represents the earth's surface, is the stage for a succession of images showing the development of human society, from its origins in pristine nature to functionalist modernist architecture. The artist used examples of architecture as a symbol for the unreflectingly progress-obsessed modern era; the examples could stand for either socialist panel-housing or Western modernist estates, demonstrating his belief that the phenomenon of ecological crisis went beyond Cold War divisions, since "the devastation knows no borders." ${ }^{20}$

A global approach to the history of civilization on earth is also

\footnotetext{
I7 Interview with the authors, Bratislava, March I5, 2007.

I8 Miroslav Kundrata, "Czechoslovakia," in Civil Society and the Environment in Central and Eastern Europe, ed. Duncan Fisher and Claire Davies (London: Ecological Studies Institute, I992), 34 .

I9 See, for instance, Auriel Hrabušický, "Out of the City," in Slovak Picture (Anti-Picture): 2oth Century in Slovak Visual Art (Bratislava: Slovak National Gallery, 2008), I49.

20 Auriel Hrabušický, "Rudolf Sikora: Activist and Observer," in Rudolf Sikora: Against Myself, 42 .
} 

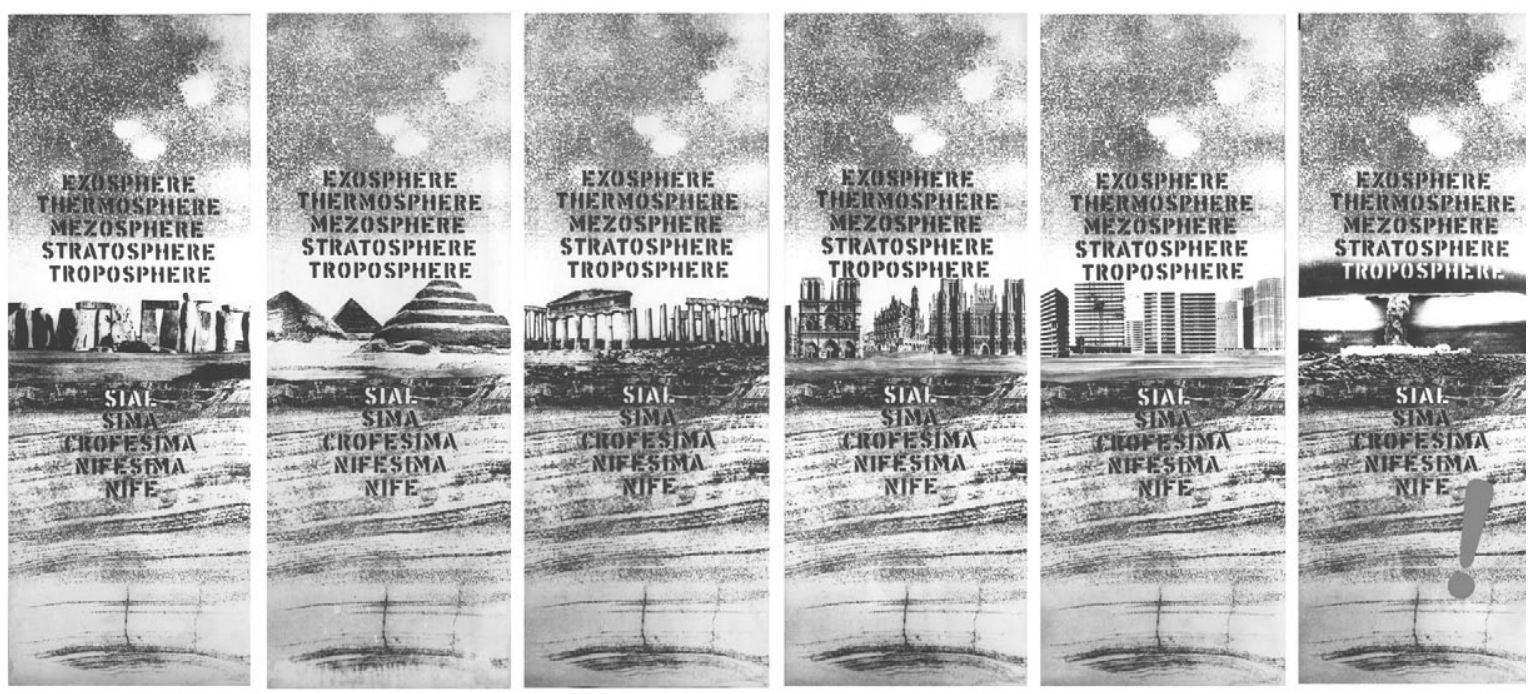

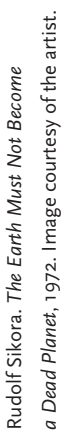

manifest in Sikora'a work The Earth Must Not Become a Dead Planet from the same year, where a similar succession of graphic sheets are labeled with precise scientific terms for the separate layers of the earth's crust and atmosphere. After setting up a vertical cross section that demonstrates the spatial domain of the planet, Sikora then brings in, in the central part of the sheets, the temporal dimension of the development of civilization, depicted again through the history of architecture. The narrative unfolds through iconic structures that range from Stonehenge in England to the Egyptian pyramids, Greek temples, Gothic cathedrals with cut-off spires, and modern skyscrapers with still-attached cranes. Here Sikora deals with the interaction of the human and natural worlds in terms of its spatial aspects, while the concluding image of the series contains a warning conveyed by a catastrophic vision of an atomic mushroom cloud. The image is indicative of the degree to which fear of nuclear destruction, which could result in a dead planet and the perishing of life on earth, had entered the popular psyche in the wake of Hiroshima and the invention of the hydrogen bomb. ${ }^{21}$

2I See David Crowley, "Looking Down on Spaceship Earth: Cold War Landscapes," in Cold War Modern: Design 1945-1970 (London: V\&A Publishing, 2008), 252. 
Sikora's use of the terminology and insights of environmental science and ecology in his works from the early I970s-reformulated as visual information in conceptual charts and diagrams-demonstrated a remarkable interest in and knowledge of environmental debates considering the restrictions on access to green ideas in the Eastern Bloc. His explorations of the longue durée of planetary time and the infinite expanses of cosmological space were in stark contrast with the narrowing of the domestic frontiers and perspectives in the wake of normalization. By expanding the parameters of his inquiry beyond the reach of the dominant ideology, Sikora carved a space for free thinking and action that offered an escape route from the sobering conditions of the present.

\section{$\mathrm{OHO}$}

The antiestablishment attitude of Slovenian group OHO, whose core members circa 1970 were Milenko Matanović, Andraž Šalamun, Marko Pogačnik, and American David Nez, arose in the spirit of youthful rebellion on the countercultural wings of I968. The longhaired artists, wearing t-shirts declaring "I Am a Hooligan" and listening to the Rolling Stones's “(I Can't Get No) Satisfaction,” disrupted the normality of the socialist everyday and expressed their discontent with mainstream society. 22 The particular character of the student protests of I968 in Yugoslavia derived from the critique contained in the motto "Down with the Red Bourgeoisie!" This slogan was directed toward the mismatch between the theory and practice of socialism, and was in fact articulated "on the grounds of official ideology." 23 OHO, however, had little in common with the left critique of socialism formulated by the circle of "ultra-leftist" philosophers gathered around the journal Praxis, drawing their oppositional attitude instead from the currents of global counterculture.

Notably, ecological concerns were low on the list of demands of political activists around I968, but it was the counterculture that

22 See Miško Šuvaković, The Clandestine Histories of OHO Group (Ljubljana: Zavod P.A.R.A.S.I.T.E., 20IO).

23 Boris Kanzleiter, "Yugoslavia," in 1968 in Europe: A History of Protest and Activism, 1956-1977, ed. Martin Klimke and Joachim Scharloth (New York: Palgrave Macmillan, 2008), 222. 
accompanied the rise of the new left that showed "environmental sentiment." 24 This is particularly important for understanding OHO's relationship to ecological philosophies, which gradually developed at the turn of the decade, starting with an attraction to arte povera aesthetics that guided them out of the gallery setting. Their awakened interest in the observation of fundamental natural processes, spatial perception, and sensuous experiences came to the fore in their summer projects of I969. ${ }^{25}$ One such action in the environment, initiated by Matanović and entitled Wheat and Rope, consisted of the artists slowly walking along opposite sides of a field holding a stretched-out line of rope, which gently bent the wheat heads as they passed. By immersing the participants in an environment that had at the same time become an inseparable part of the work, this highly ephemeral and unobtrusive gesture was characteristic of OHO's exploration of the phenomenological dimensions of natural sites, as well as being indicative of their growing interest in the radical erasure of the distinction between art and life. In Zarica Valley near Kranj, the artists reflected freely on their experience of a harmonious relationship with not only the natural surroundings but also the cosmos, as for instance in Matanović's Arrangement of Candles on a Field Corresponding to a Constellation of Stars in the Sky 30 IV 1970, in which the artist laid out candles on the ground to precisely mirror the positions of the stars.

In the late ig6os, imagery of the cosmos was flooding the popular imagination, fuelled by the space race, the recent moon landing, and the first photographs of planet Earth taken from space. This gave rise to many science-inspired artistic reflections, as we have seen with Sikora's practice. The Slovenian artists, however, chose instead to focus on the mystical dimensions of the cosmos. Setting out to achieve harmony between self and cosmos, they investigated cycles of energy flows, the constellations of the universe, the powerful order of symmetry, and conceptions of time and space as conveyed in the wisdom of ancient worldviews, Eastern religions, and Western esoteric traditions, while at the same time deepening their ecological awareness. Their interest in the relationship to higher cosmic dimensions also led

\footnotetext{
24 Christopher Rootes, “The Environmental Movement," in Klimke and Scharloth, 1968 in Europe, 297.

25 See Igor Zabel, "A Short History of OHO," in OHO Retrospective, ed. Igor Španjol (Ljubljana: Moderna Galerija, 2007).
} 


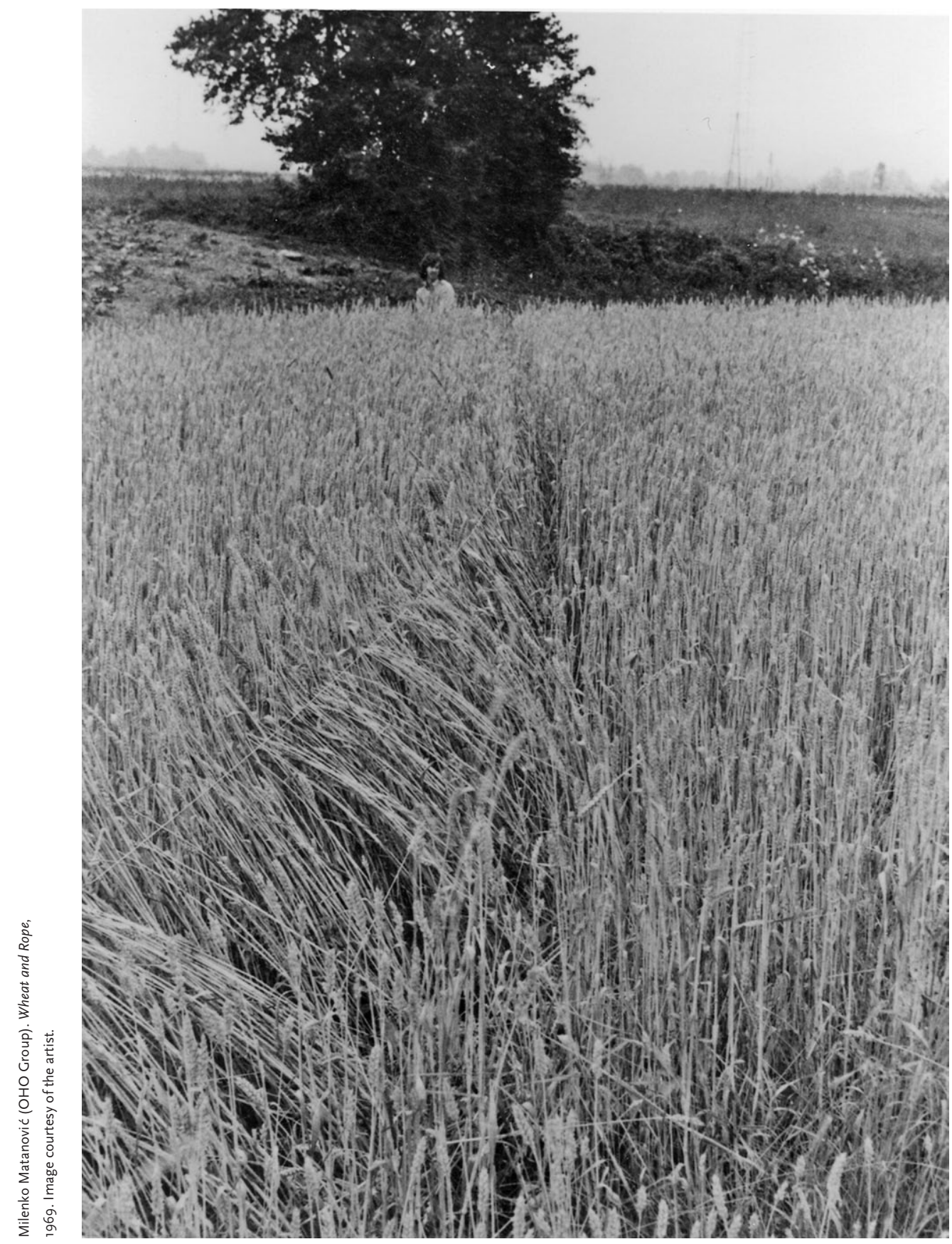


them into explorations of group consciousness that involved the creation of therapeutic situations and experiments in psychic communication, which they referred to as "schooling." Set in the countryside, these group exercises were designed to bring about a heightened sensitivity to the natural environment and involved collective rituals of working, eating, breathing, and walking together that were about "re-disciplining the liberated body" through practices of meditation in order to "re-harmonize with the universe." 26

Their journey from

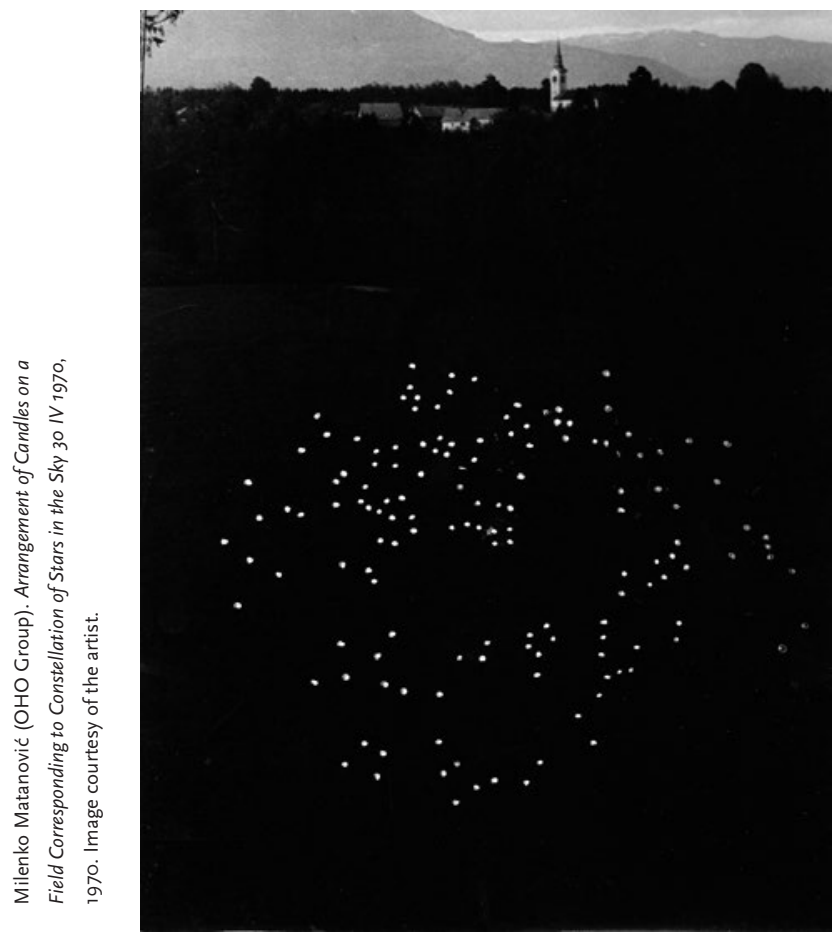
the investigation of ideas and concepts toward radical experiments in collective existence steered the members of $\mathrm{OHO}$ toward a momentous decision: to break completely from the restraints of civilization, including participation in the institutional art world, and found a rural commune. The Šempas commune was established on April II, I97I, when an $\mathrm{OHO}$ group of family and friends (fourteen people altogether) moved to an abandoned farm in the Vipava Valley and started to farm the land, turning the derelict house into a livable space and leading a self-sustained life with only minimal interaction with the outside world. Inspired by personal experiences at the New Age spiritual community of Findhorn Centre of Light in Scotland, ${ }^{27}$ their

26 Igor Zabel, "Short History of OHO," I27.

27 See Aleš Crnić, "Changing Concept of New Age," Journal of Alternative Spiritualities and New Age Studies 4 (2009): 25 . 


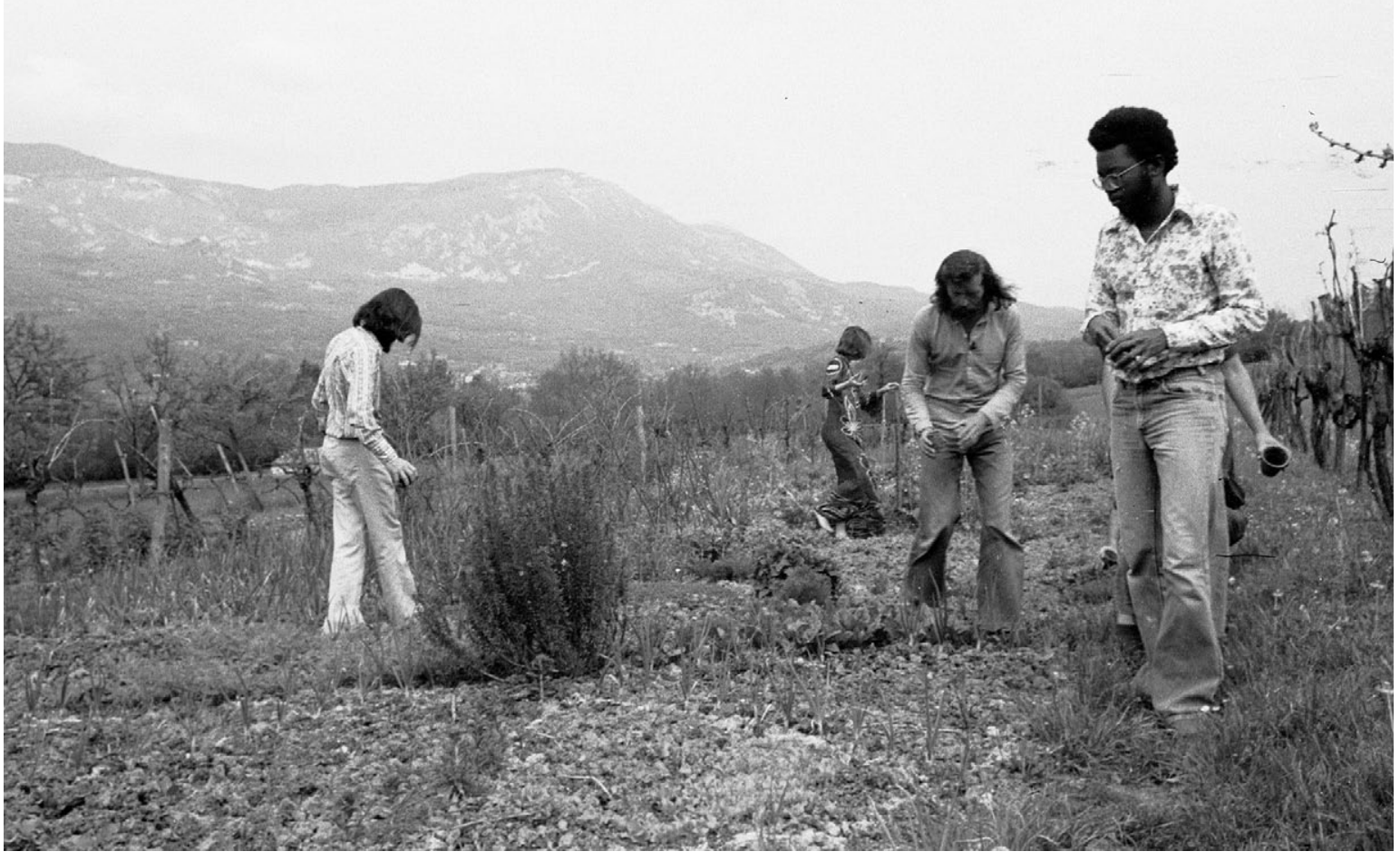

decision to drop out, despite promising international careers, ${ }^{28}$ was a political act that shocked the art world and drew the artists closer to an ecological agenda.

While OHO's practice had long shown a concern with natural and cosmic dimensions and had involved enacting a spiritual and corporal harmony through meditation and ritual, it was only after they moved to the countryside and began to actually cultivate the land that their interest in environmental issues crystallized. Marko Pogačnik, who still lives on the farm, told a rare visiting journalist in 1974 that "man is polluting nature and nature is taking revenge; we want to live in indigenous nature in which there is no asphalt, electricity, polluted atmosphere, or money." 29 The force of OHO's ecological critique derived from their rejection of the values and models of industrial society in both its socialist and capitalist guises, while the group's underlying

28 They took part, for instance, in the Information exhibition at the Museum of Modern Art, New York; see Kynaston McShine, Information (New York: Museum of Modern Art, I970), exhibition catalog.

29 Salihz Vizdić, "Pobjegli od civilizacije” [Escape from Civilization], Večernji List (Zagreb), April 20-2I, I974. Authors' translation. 
political character flowed from their bold decision to withdraw from the dominant system rather than submit to the inevitable processes of appropriation and assimilation of radical gestures that remain within the confines of the art world.

\section{PETR ŠTEMBERA}

Insightful criticism of the dominant approach to nature within socialist systems arose amongst ecologically attuned neo-avant-garde artists across Eastern Europe around 1970, reflecting the growing realization that both official Marxist ideology and the practice of real existing socialism were uncaring of and damaging to the natural world. Although evidence of the environmental destructiveness of Soviet-style industrialization and the massive construction projects that, since Stalin, had left a permanent mark on whole ecosystems was not to emerge in the public eye until the twilight of communism, the story of a little dog sacrificed on the altar of Soviet efforts to get ahead in the space race laid bare the regime's harshly instrumental attitude to animals. The story of Laika, rising above geopolitical divides, became at the same time a focus for feelings of interspecies empathy associated with the rise of the animal rights movements of the I970s. ${ }^{30}$

The particular resonance of the fate of Laika, Russia's first canine cosmonaut, lies in the mismatch between the imagery of a Cold War publicity stunt that took place on November 3, 1957-in which "pictures of a Soviet mongrel dog travelling in space looking as comfortable as if she were on a car journey were beamed down to an incredulous American public" — and the reality that Laika died of overheating after only six hours, rather than surviving for four days in orbit before being painlessly put to sleep, as Soviet propaganda long maintained. ${ }^{31}$ Although animals also died in the rival American space program, the treatment of Laika raised particular ethical concerns. There was no adequate scientific justification for the decision not to provide her with a return capsule, and the stunt was a direct result of Khrushchev's haste to secure a symbolic victory in the space race. ${ }^{32}$

30 For the global and cross-generational appeal of the story of Laika, see the autobiographical novel MY Life as a Dog by Reidar Jönsson (New York: Farrar, Straus and Giroux, I993) and the film of the same name directed by Lasse Hallström (I985).

3I Deborah Cadbury, Space Race: The Epic Battle Between America and the Soviet Union for Dominion of Space (New York: Harper Collins, 2006), 169-70.

32 See Asif A. Siddiqi, Sputnik and the Soviet Space Challenge (Gainesville: University Press of Florida, 2000), I72. 
One member of the East European neo-avant-garde to confront the culturally and ideologically imposed divide between humans and animals, as well as the problem of alienation from the natural world, was Czech performance artist Petr Štembera. It was "in an extraordinary way," as Czech art critic Jindřich Chalupecký recalled, that Štembera "problematized the interrelationship between man and the natural process, living plants and animals." 33 Through a succession of performances, which were often realized with the participation of animals, including a hamster, fish, ants, and a hen, whose equal and nonhierarchical treatment by the artist was in sharp contrast to the communist authorities' instrumental approach to animals, the artist addressed the problem of belonging in relation to the natural world. His actions demonstrated that the world should be experienced through all the senses, but they were more than just neutral exercises in phenomenology: they also suggested a heightened awareness of the crucial value of nature for human beings.

In the artist's account of his 1976 performance Parallel Deprivation with Hamster, Štembera narrates how after a period of three days, during which both artist and animal had gone "without any liquid intake, I offered myself and a hamster wine to drink, every morning and evening over the next few days. The action was to and did end when one of us, in this case the hamster, took a drink." ${ }^{34}$ Although the performance could be interpreted on one level as a comment on the injustice and deprivations experienced in normalization-era Czechoslovakia, the situation of temporary equality created between the artist and the hamster within the context of the performance points to the artist's consistent efforts to test the unbridgeable abyss that separates humans from the nonhuman world.

One of Štembera's most extreme performances was Grafting, which took place in April I975 when the artist decided to implant a small branch of a fruit tree under the skin of his forearm in order to demonstrate his unity with nature. As the artist explained, he wanted to "make contact with the plant, put it in my body, to be together with it

33 Jindřich Chalupecký, Novéuměnýv Čechach [New Czech Art] (Prague: H+H, I994), I46. Authors' translation.

34 As a Czech, Štembera was a dedicated beer drinker. Štembera in Karel Srp, Karel Miler, Petr Štembera, Jan Mlčoch, 1970-1980 (Prague: Gallery of the City of Prague, I997), 34 . 


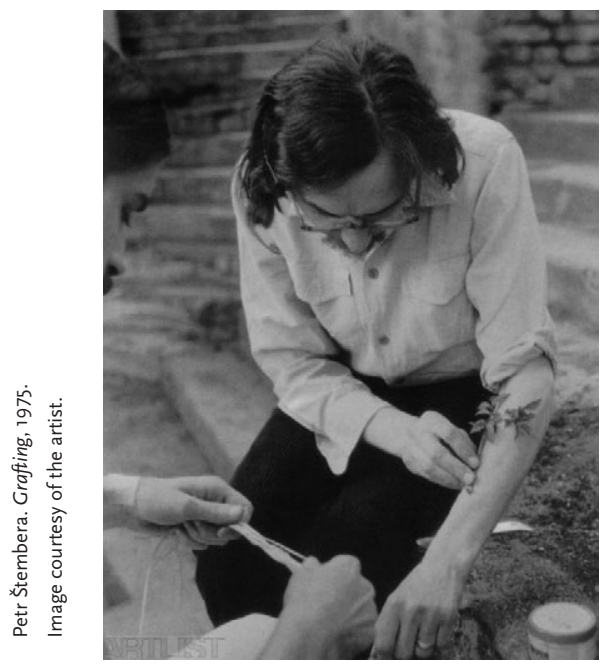

as long as possible. ${ }^{35}$ Štembera left the stem under his skin for the rest of the day, but the wound became badly infected and he was forced to see a doctor. Shortly afterward, Štembera performed another piece, which he explains like this: "After three days and nights without sleep I spent the fourth night in a tree." ${ }^{36}$ For an action performed in the summer of 1976 , he dug a hole near the roots of a tree with his own hands, at a spot where he would "occasionally spend the night. ${ }^{{ }^{37}}$ It is remarkable that in all three performances the artist used his body to communicate with and receive impulses from the environment by exposing it to extreme conditions, questioning the limits of the possibility of experiencing unity with the natural world, without attempting to provide any final answers. His noninstrumental and nonprogrammatic approach could be distinguished from that of other neo-avant-garde artists of his generation, who tended to be more human-centered.

Whereas many live artistic actions had taken place on the streets of Prague in the Ig6os in direct encounters with the citizens, what followed after the crushing of the Prague Spring was described as "a clearing of public space," and as a consequence, "Czech performances moved inwards. ${ }^{\prime 38}$ In other words, artists resorted to private apartments and occasional excursions to the countryside in the quest to express their artistic freedom and to circumvent official restrictions, while body and action art became the favored forms of expression. Štembera was one of the few to also face outward: despite severe state restrictions on travel, he managed to take an active role in the international art world, becoming the focal point for international contact with

3

Kristine Stiles, "Inside/Outside: Balancing between a Dusthole and Eternity," in Body and the East: From 1960 s to the Present, ed. Zdenka Badovinac (Ljubljana: Moderna Galeria, 1998), 24.

36 Štembera in Srp, Karel Miler, Petr Štembera, Jan Mlčoch, 37.

37 Ibid.

38 See Jiři Ševč́́k, "Between a Shaman and a Clown," in Badovinac, Body and the East, 46. 


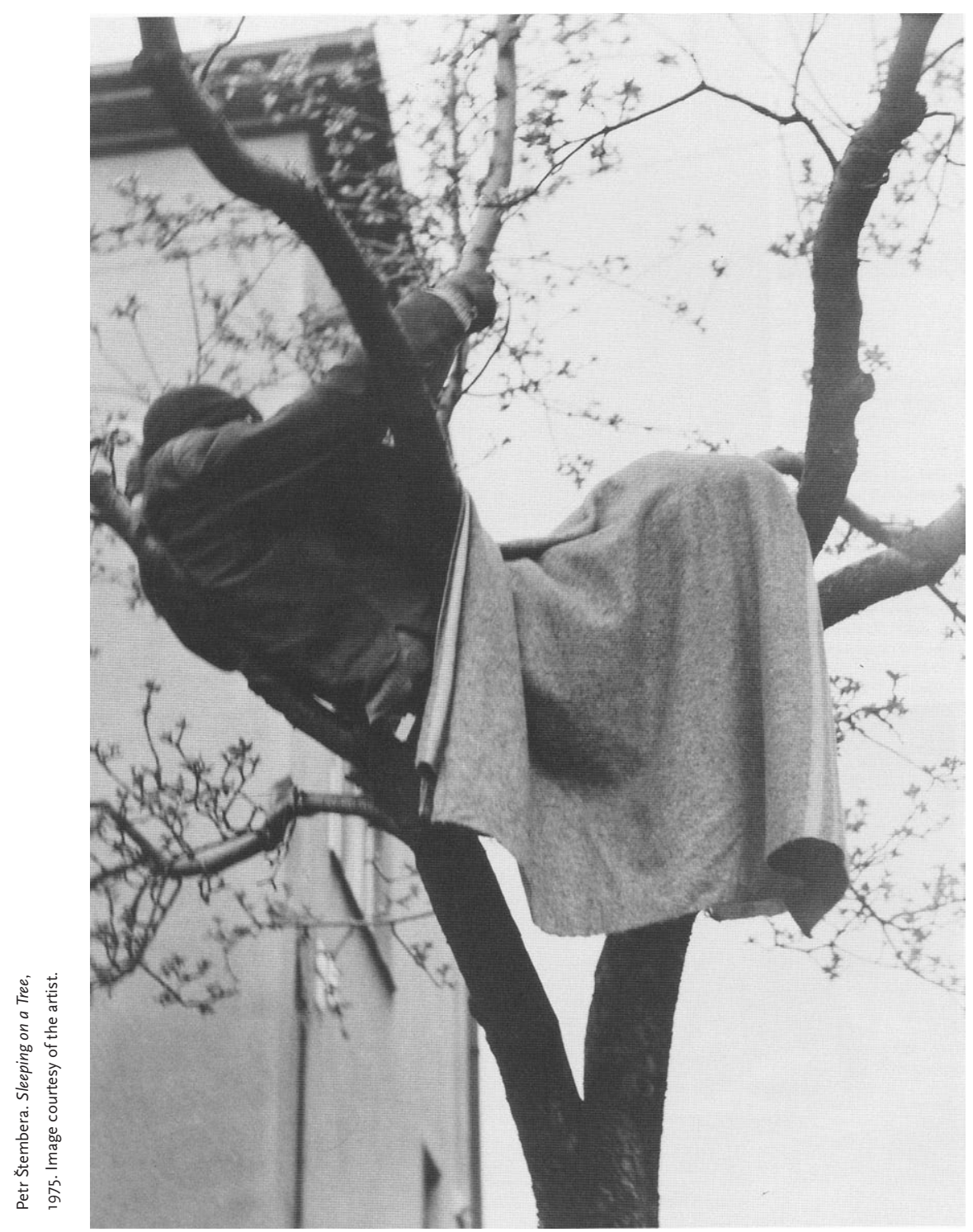

the Czech art scene, albeit in absentia and relying on the postal service. His frustration with such conditions contributed to his decision to abandon art practice altogether in 1980.39

Štembera's awareness of the complex issues around ecology are manifest not only in his performances but also in a text he wrote for the exhibition Nature, held at the Institute of National Design in Prague in I976. In it, he elaborates on artists' relations to the natural world, distinguishing between land artists and those who are more ecologically

39 He was one of the very few East European artists to be included in Lucy Lippard, Six Years: The Dematerialisation of the Art Object, 1966-72 (London: Studio Vista, I973), I69-70. 
attuned, concluding that there is a "turn in the thought of artists who, just like numerous architects, town planners, ecologists, economists, and others, have reached an awareness of the indispensability of nature for human beings in the present, and perhaps also for their future survival." ${ }^{\prime 0}$ Such passages demonstrate that despite the deprivations in terms of the availability of information in the Eastern Bloc, similar environmental ideas were expressed synchronously across the world.

Štembera's exceptional position in the history of neo-avant-garde engagements with ecology in Eastern Europe reflects his deep understanding of environmental issues, which he approached from a distinctive theoretical position. At the same time, it is noteworthy that no specific environmental program can be detected in his performances, nor can his approach to the environment be said to have been motivated by the romantic call for a "return to nature," which appealed so strongly to the countercultural movements of the ig6os, as could be seen in the case of the OHO group. Štembera's approach to the environment should rather be viewed as an embodied existential inquiry into the possibility of a nonhierarchical relationship to the natural world.

Alienation from the natural world, which Štembera voiced in his practice, was an issue addressed by neo-Marxist sociologist Rudi Supek in his 1973 book This Only Earth. Supek's work, written in the immediate aftermath of the UN Summit in Stockholm, was one of the earliest introductions to environmental discourse in Eastern Europe. ${ }^{41}$ Seeking to challenge the widespread assumption that Marx lacked an ecological dimension, Supek, who was associated with the Praxis group in Yugoslavia, highlights Marx's writings on the "dialectics of alienation" and his discussion of the need to bring the "form of production" into harmony with the "true needs of man," arguing that "the whole problematic of alienation contains within itself the question of the relation of man to nature." Significantly, and typically for the reformist neoMarxist circles of third-way Yugoslavia, he argues that the question of alienation "has been completely left out of the dogmatic conception of Marxism that is recognized as the official version in the Soviet Union." ${ }^{42}$

40 Unpublished text written by the artist for the opening of the exhibition Nature, entitled "Uměný a př́roda," 3. Authors' translation.

4I Supek, Ova jedina zemlja. Supek took part in the parallel events of the Stockholm Summit, specifically the meetings of the transnational peace group Dai Dong. 
TOK

The tangential relationship to state socialism that Yugoslavia took can also be detected in its slightly more open approach to the exchange of environmental ideas-which, however, were still kept within ideological control and treated as an apolitical issue that served handily as a diversion from the resurgence of nationalism that threatened the disintegration of the federal republics. At the height of the Croatian Spring in I97I, the main art journal Zivot umjetnosti pointedly chose not to comment on daily political upheavals, but published instead an extensive and informative double issue devoted to art and ecology. ${ }^{43}$ A year later, when its editor in chief was the curator of the "Proposal" section for young artists at the annual Zagreb Salon exhibition, he proclaimed that "a major concern of our civilization is the human environment," "which served as the thematic focus for this edition of the show. It was in this context that the group TOK, whose core members were Vladimir Gudac, Dubravko Budić, and Davor Lončarić, realized a series of public artworks that critically and directly dealt with current environmental problems, as well as the related aspect of alienation in socialist society.

Foregrounding the problem of public space in the urban environment, TOK declared that "there are two important modes to how we think about it - the ecological and the 'intimate,' which challenges the current technicist and technocratic approach to the city"; furthermore, according to the artists, the city entails "the gradation of space which can be reduced to the dichotomies outer/inner, open/closed, as well as public/intimate." ${ }^{45}$ Their preference for the notion of "intimate" as a pairing with "public" is significant: the more common antonym of public, after all, is private, which was a loaded and contested term under communist rule, where private property had been abolished; moreover, intimate derives from the Latin intimus, referring to being closely acquainted and familiar, and in that sense the choice of this word reveals TOK's interest in questioning the citizen's personal relationship to public space.

43 See Żivot umjetnosti (Zagreb) I5-I6 (I97I).

44 Žarko Domjan, 7. Zagrebački salon (Zagreb, I972), 5, exhibition catalog.

45 "Grad kao totalno zbivanje” [City as Total Happening], Telegram (Zagreb), 2 June, I972, I7. Authors' translations. 


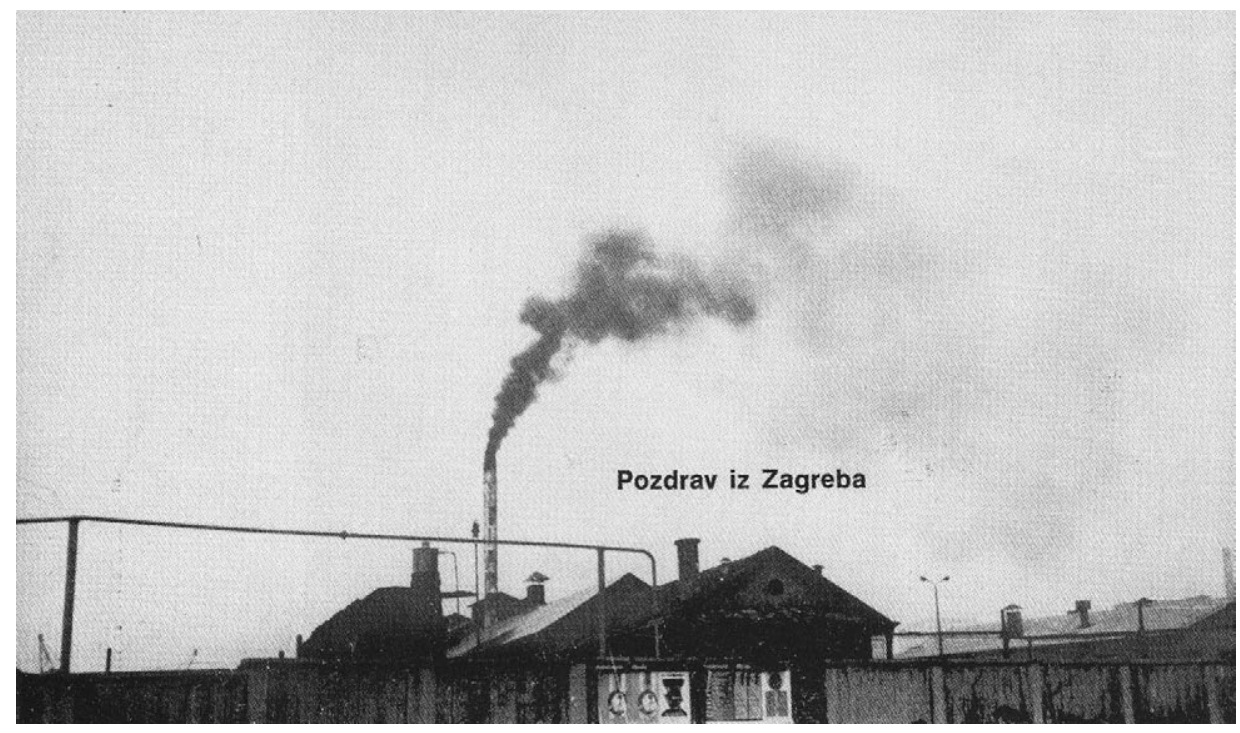

Although socialist public space was first and foremost an ideological ground for the forging of collective identity during closely orchestrated official celebrations, for the rest of the time these spaces were neglected and uncared for. Reflecting on this situation, the group's aim was to "get hold of the alienated space for public use and make nobody's public space intimate." ${ }^{46}$ The action that most directly addressed this problem involved the symbolic cleaning of several square meters of the main square in Zagreb, during which the pavement was first swept and then washed with brushes by the artists, who were on their knees as if cleaning their own apartments. In another project they installed pocket-sized mirrors at busy spots in town, for the purpose of making the exteriors of the city more intimate, while at the same time giving passersby a chance to take a glance at themselves and, in that act, to see the urban surroundings behind them in the process.

Referring to the problems of pollution and waste, TOK artists conceived several projects that addressed these pressing environmental questions directly, including designing transparent rubbish bins that were installed at several locations in the city center during the month-

46 Vladimir Gudac, "The TOK Group during 1972 and I973," in Budić: Between Gesture and the Programme, ed. Marinko Sudac (Zagreb: Edicija Sudac, 2007), 22. 
long Salon exhibition. At a time when the mass production of new synthetic materials left in its wake the unprecedented image of mountains of nondegradable waste on city dumps, the see-through bins were a reminder to the populace that litter does not disappear once it is thrown into a bin,. Furthermore, in their postcard Greetings from Zagreb they depict an alternative vista of the city showing a factory chimney with smoke billowing out, directly disclosing the air pollution of the capital and offering a sharp contrast to the picturesque views typically selected for postcards.

Another aspect of the environmental situation of the I970s was tackled by TOK in a project that involved leaving traces of car tires along lines of parked cars, and in this way marking the space on the pavement left for pedestrians. The artists also dipped a tire in black paint and rolled it along the pavements in the city center, thereby commenting on the new situation in the use of city space, but also pointing to environmental issues that were connected to the growing use of the personal car. The rapid increase in the number of cars led to new destruction of landscape, as more and wider roads were built, and produced unheard of traffic jams, resulting in the wasteful use of fossil fuels and contributing to the perception that cars were the main cause of air and noise pollution. The disruption of urban space by cars was further emphasized by the artists in their act of placing a tire in the entrance to Zagreb's main department store, NAMA, over which all the shoppers had to step, offering an additional comment on the moderate consumerist boom in Yugoslavia since the ig6os.

A slightly different set of issues was emphasized in projects that confronted the problems of city inhabitants and their social relations. For instance, oversized cartoons set up in the city center had their backgrounds cut out, and so inventively turned the real city surroundings into a backdrop for mini-dialogues between cartoon characters that were conveyed in speech bubbles. One such exchange consisted simply of the phrase "Inače?" — which literally means "Well?" and in colloquial Croatian is used to ask "What's up?" The emptiness of the expression for TOK indicated the level of alienation between the citizens and elevated the question of intimacy from city space to human interrelations. The implication of this work is that, contradicting the assumptions of official Marxism, alienation was not just a feature of capitalist societies, but also afflicted the citizens of socialist cities. 
TOK, which was primarily formed around the Salon exhibition in I972 and afterward did not continue its collective activities for much longer, caused problems for moderate, modernist Yugoslav art critics. Although begrudgingly acknowledged as belonging to the progressive "new artistic practice" of the period, their socially engaged public art that directly interacted with the citizens was dismissed as the work of "a troupe of travelling entertainers" who were spreading a social rather than an artistic message. ${ }^{47}$ The conventional role of art was also parodied by TOK in an unannounced action that took place during the Salon, when the artists paraded through the streets of the capital carrying banners adorned with abstract patterns, such as black and white stripes, dots, and grids. By re-enacting the demonstrations that were a common sight during the Croatian Spring of I97I, the artists extended their ecological critique to address the "double pollution of our living space" ${ }^{\prime 4}$ - in other words, the pollution of the real physical environment and of the domain of the human psyche.

\section{CONCLUSION}

The range of artistic approaches to the environment under socialism turned out to be as varied as the terrain of Eastern Europe, where the ebbs and flows of state ideology contributed to unevenness both in access to current environmental thinking and in the degree of receptivity to ecological ideas. Other factors influencing the form and direction of neo-avant-garde engagements with ecology included the extent to which artists had opportunities to travel and take part in international artistic currents and whether there was any institutional support for their efforts. Where Štembera and Sikora were denied the possibility to exhibit at all in officially controlled art spaces, the situation facing $\mathrm{OHO}$ and TOK in Yugoslavia was in this respect quite different: although ecology was tolerated, in a manner strangely parallel to the official acceptance of modernist art, this was on the condition that it remain devoid of any political connotations, reflecting a more subtle control mechanism that $\mathrm{OHO}$ was to reject with their decision to drop out of the system. In addition, although these artists were informed about ecology, they made a choice whether to refer to environmental

47 Marijan Susovski, Innovations in Croatian Art of the 1970 (Zagreb: Gallery of Contemporary Art, I982), 31.

48 Gudac, “TOK Group," 22. 
issues in their work more directly, as in the cases of Sikora and TOK, or at a more implicit level, as with Štembera and OHO.

It is important to emphasize that artistic engagements with ecology in Eastern Europe arose in tandem with the spread of environmental thinking across the globe from the I96os onward, coinciding with the appearance of environmentally attuned artistic experiments elsewhere in the world. At the same time, artists living and working in the conditions of "real existing socialism" necessarily developed their own environmental critique in the light of a range of specific factors, from the legacy of Stalinist hostility to nature to forlorn later attempts by the authorities to deny the existence of environmental problems under socialism. Their work voiced a powerful critique of contemporary society, both on the level of challenging the environmental negatives of the socialist system and by giving precedence to the earth over ideological divides. Finally, their artistic visions and ecological insights-whether they take a more scientific, mystical, experiential, or activist direction-have an enduring relevance for a world that is still grappling with the ecological crises clearly recognized by their generation. 